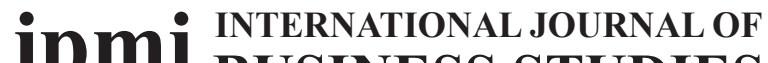 BUSINESS STUDIES
}

ISSN: 2580-0132

Vol. 1 | No. 1 (June 2017)

\section{The Role of Subsidiary Manager Under Resource-based Paradigm}

\author{
Harris Turino Kurniawan ${ }^{1^{*}}$ \\ ${ }^{1}$ Sekolah Tinggi Manajemen Ipmi, Jakarta 12750, Indonesia
}

\begin{abstract}
A B S T RACT
The role of subsidiary managers, as middle managers in Multinational Corporation (MNC) structure, has received increasing scholars' attentions recent time. They are believed to have great influences to facilitate various strategic activities, especially in developing subsidiary capability, hence contributing to subsidiary development. Research to investigate subsidiary manager roles and managerial process in subsidiary level, however, are relatively rare. I propose an alternative framework to fill the gap, by employing recent development of resource-based theory, i.e. resource orchestration. I argue that subsidiary manager can be treated as a mediator between resource allocated by corporate headquarter (and also from local partners in strategic alliance formation) and the various steps in resource orchestration.
\end{abstract}

ARTICLE INFO

Subsidiary Manager,

Resource-based,

Resource Orchestration.

Multinational Corporation.
${ }^{*}$ Corresponding author Email: harris.turino@ipmi.ac.id

Copyright $@$ 2017Authors. This is an open access article distributed under the Creative Commons Attribution License, which permits unrestricted use, distribution, and reproduction in any medium, provided the original work is properly cited.

\section{BACKGROUND}

Subsidiary development is one of the recent research streams of multinational management literature that has attracted many scholars' attentions (Harzing, 1999). It is recognized that subsidiaries evolve over time and, through their own actions and initiatives, have the potential to develop and modify their capabilities (Birkinshaw \& Hood, 1998) to provide contributions for themselves, corporation and or their host countries (Paterson \& Brock, 2002). Among huge of researches on subsidiaries activities, however, little is known about the role of the subsidiary manager in this managerial process (O'Brien et al, 2012). This prevents our understandings about the face and array of skills required to be successful in the modern multinational corporation (MNC).

Subsidiary managers have a unique position in MNC structure because they act as a mediator between MNC's strategy and day-to-day activities (Wooldridge, Schmid \& Floyd, 2008). However, their role is not only tying MNC's strategy into practice, but also synthesizing information (e.g. Dutton et al, 1997), championing alternatives (e.g. Bulgerman, 1983; Kanter, 1982), and facilitating adaptability (e.g. Mudambi, 1999; Rugman \& Verbeke, 2001). Barlett and Ghosal (1997) argued that in recent modern MNC, subsidiary managers are not enough 
to act as strategy implementer, but their more importance role is an as aggressive entrepreneur. This is consistent with Floyd and Wooldrige (1994) that stated subsidiary managers as a dynamo of subsidiary's growth.

The discussion of this writing focuses on subsidiary manager role to facilitate the development of subsidiary's capability to adapt the dynamic of host country where the subsidiary operates. The purpose is to apply recent development of prosess perspective of resource-based theory, i.e. resource orchestration (Sirmon et al, 2011), that has potential to enrich the research of subsidiary manager role in subsidiary management.

\section{SUBSIDIARY CAPABILITY DEVELOPMENT}

The capability is routine or business process that reflects a bundle of complex knowledge owned by the organization (Day, 1994; Teece et al, 1997) to combine or utilize a set of resources to perform a specific task (Helfat \& Peteraf, 2003). In business literature, the capability has advanced to the prime determinant of the MNC's performance (Schmid \& Schurig, 2003) so that the development of capability that is able to respond environmental changes will improve performance (Teece, 2007). Capability development can be in the form of strengthening and enhancing old routines or creating a new routine (Birkinshaw \& Hood, 1998). It is simply concluded that ability to develop capability needs an understanding of environmental context.

Host countries are often perceived as unfamiliar environments by a foreign subsidiary. It creates high levels of uncertainty that impede effective decision making, leads to difficulties in dealing with local governments and partners, (Pedersen \& Peterson, 2004), and finally reduce subsidiary's ability to develop its capability. The root of these difficulties is the foreign subsidiaries' lack of local market knowledge that influences both resource commitment to the foreign market (Johanson \& Vahlne, 1977), and their performance of business activities (Subramaniam \& Watson, 2006). Thus, the key success factor to cope these difficulties is learning to absorb local knowledge as fast as possible, and then exploit it to commercial ends (Petersen etal, 2008).

One source of learning for subsidiary and its manager is by managing resource committed by corporate headquarter to host country (Johanson \& Vahlne, 1977). If foreign subsidiary allies with local partners, it will create resource complementarities (Adegbesan, 2009) that become a unique and more valuable source of learning (Inkpen, 1998) that fasten the absorption of local knowledge (Pennings et al,1994). This is a learning process which calls on subsidiary to interpret the world, uncover new market opportunities, focus existing resources, accumulate new resources (Floyd \& Wooldridge, 1994). Under resource-based and dynamic capability logic, unique source of learning has potential to provide rare and inimitable knowledge to develop superior subsidiary capability (Dyer \& Singh, 1998; Helfat et al, 2007).

\section{RESOURCE ORCHESTRATION IN SUBSIDIARY CONTEXT}

Traditionally, resource-based theory hypothesizes that having VRIO (valuable, rare, inimitable, organization) will lead a firm to achieve competitive advantage. However, VRIO resources only contained potential value so that it does not guarantee the value creation (Sirmon, Hitt \& Ireland, 2007). Optimum realized value will not occur if the firm is bad in managing its resources (Ketchen, Wowak \& Crighead, 2014). Resource orchestration is a process perspective of the resource-based theory that basically explains the conversion of the potential value of firm resources into realized value, by accommodating organizational learning, knowledge management and environmental contingency (Sirmon et al, 2007). Barney et al (2011) state that resource orchestration will be one of the future research areas of resource-based theory.

Resource orchestration is concerned with the actions which managers take to facilitate efforts to effectively manage the firm's resources' (Sirmon et al, 2011). More specifically, managers influence firm performance by structuring the firm's resource portfolio, bundling resources, and leveraging those 
resources in the marketplace (Ireland, Hitt \& Sirmon, 2003; Sirmon et al, 2007). The firm may structure its resources through acquisition, accumulation or divestiture. Firm's resource portfolio will open the opportunities to develop various capabilities through three alternative ways of bundling, i.e. stabilizing, enriching, and pioneering. Finally, firm may exploit its resources and capabilities to serve target customers through three sequential steps: mobilizing, coordinating and deploying.

Developing resources and capabilities are one of the strategic activities conducted by subsidiary management (Barney \& Pedersen, 2009). In international business literature, however, investigations of how resource and capability built are relatively rare (Ludwig \& Pemberton, 2011; Peng, 2001). The birth of resource orchestration provides potential to fill this gap, and in the same time, it also explains the role of manager subsidiary in subsidiary management as stated by O'Brient et al (2012).

I develop an example of a framework to apply resource orchestration in subsidiary management (see Figure-1). The role of the subsidiary manager is put as a mediator between resources allocated by the parent (both from foreign parent and/or local parent if strategic alliance formed), and the process of resource orchestration. In this framework, resources allocated by a parent is given, and become the source of learning (to get local knowledge) that influence subsidiary manager capability and can be exploited to orchestra subsidiary's resources and capabilities. Under dynamic capability paradigm, the subsidiary manager can be manifested in the form of dynamic managerial capabilities that is built upon three basic components, i.e. managerial human capital, managerial social capital and managerial cognition (Adner \& Helfat, 2003). It is also operationalized by AMO (ability, motivation, opportunity) concept that is often used to identify the successful to perform a specific task (Chang etal, 2012).

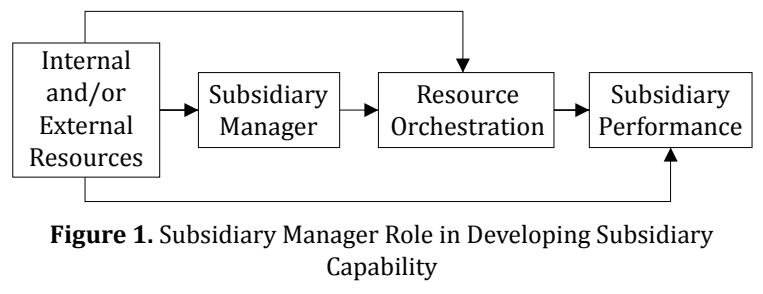

Maritan and Peteraf (2011) proposed to bridge the two ways of how a firm gets its resources, i.e. acquisition (Barney, 1986) and accumulation (Dierickx \& Cool, 1989). The acquisition is getting tradable assets from external sources (e.g. from strategic factor market, from corporate headquarter, from partner), while accumulation is developing assets internally (usually for nontradable assets). Acquisition and accumulation can be seen as a sequential process (Barney, 1989) so that both can be investigated together (Maritan \& Peteraf, 2011). We can modify framework in Figure1 by considering internal and/or external resources as resource acquisition and replacing resource orchestration with resource accumulation. Then we get the subsidiary manager acts as a bridge between them.

It also opens to make a variation by accommodating other constructs, such as absorptive capacity and environmental context. For example, absorptive capacity can be treated as a moderator of the relationship between internal and/or external resource and subsidiary manager, and also between subsidiary manager and resource orchestration. This condition will enhance our understanding that knowledge absorption does not depend on individual subsidiary manager only, but also depends on the ability of subsidiary (as an organization) to acquire and assimilate new knowledge. Environmental context (e.g. market dynamism, the level of competition) can also be put as a moderator between resource orchestration and subsidiary performance, or between subsidiary manager and resource orchestration, or as a determinant of resource orchestration itself.

\section{CONCLUSION}

Resource Orchestration has considerably advanced our understanding on the role of the subsidiary manager in creating resource complementarities 
that become a unique and more valuable source of learning that fasten the absorption of local knowledge. This is a learning process which calls on subsidiary to interpret the world, uncover new market opportunities, focus existing resources, accumulate new resources. Under resource-based and dynamic capability logic, unique source of learning has potential to provide rare and inimitable knowledge to develop the superior subsidiary capability.
This will enrich the development of resource-based theory application in global context. A steady stream of empirical, as well as conceptual, studies, especially from the subsidiary perspective will be interesting topics for resource-based theory scholars.

\section{REFERENCES}

Adegbesan, J. A. (2009). On the Origins of Competitive Advantage: Strategic Factor Markets and Heterogeneous Resource Complementarity. Academy of Management Review, 34, 463-475.

Adner, R., Helfat, C.E. (2003). Corporate Effects and Dynamic Managerial Capabilities. Strategic Management Journal, 24 (10), 1011-1025.

Barlett, C.A., Ghoshal, S. (1997). The Myth of the Generic Manager: New Personal Competencies for New Management Roles. California Management Review, 40(1), 92-116.

Barney, J.B. (1986). Strategic Factor Markets: Expectation, Luck, and Business Strategy. Management Science, $32(10), 1231-1241$.

Barney, J. B. (1989). Asset Stock Accumulation and Sustainability of Competitive Advantage: A Comment. Management Science, 35, 1511-1513.

Barney, J.B., Ketchen, D.J., Wright, M. (2011). The Future of Resource-Based Theory: Revitalization or Decline? Journal of Management, $37(5)$.

Birkinshaw, J., Hood, N. (1998). Multinational Subsidiary Evolution: Capability and Charter Change in Foreign-Owned Subsidiary Companies. Academy of Management Review, 23 (4), 773-795.

Birkinshaw, J., Hood, N., Jonsson, S. (1998). Building Firm-Specific Advantages in Multinational Corporations: The Role of Subsidiary Initiative. Strategic ManagementJournal, 19 (3), 221- 241.

Birkinshaw, J., Pedersen, T. (2009). Strategy and Management in MNE Subsidiaries. In A. Rugman, The Oxford Handbook of International Business, (eds). Oxford: Oxford University Press.

Burgelman, R.A. (1983). Corporate Entrepreneurship and Strategic Management: Insights from a Process Study. Management Science, 29,1349-1364.

Chang, Y., Gong, Y, Peng, M. (2012). Expatriate Knowledge Transfer, Subsidiary Absorptive Capacity, and Subsidiary Performance. Academy of ManagementJournal, 55 (4), 927-948.

Day, D. (1994). Raising Radicals: Different Processes for Championing Innovative Corporate Ventures. Organization Science, 5, 148-172.

Diericks, I., Cool, K. (1989). Asset Stock Accumulation and Sustainability of Competitive Advantage. Management Science, 35 (12), 1504-1513. 
Dutton, J.E., Ashfold, S.J., O'Neill, R.M., Wierba, E.E. (1997). Reading the Wind: How Middle Managers Assess the Context for Selling Issue to Top Managers. Strategic ManagementJournal, 18 (5), 407-423.

Dyer, J.H., Singh, H. (1998). The Relational View: Cooperative Strategy and Sources of Interorganizational Competitive Advantage. Academy of Management Review, 23 (4), 660- 679.

Floyd, S.W., Wooldridge, B. (1994). Dynosaurs of Dynamos? Recognizing Middle Management's Strategic Role. Academy of Management Executive, 8(4), 47-57.

Floyd, S.W., Wooldridge, B. (1997). Middle Management's Strategic Influence and Organizational Performance. Journal of Management Studies, 34, 465-85.

Floyd, S.W., Wooldridge, B. (2000). Building Strategy from the Middle: Reconceptualising Strategy Process. Thousand Oaks, CA: Sage.

Harzing, A. (1999). Managing the Multinationals: An International Study of Control Mechanisms. Northampton, MA: E. Elgar.

Helfat, C.E., Peteraf MA. (2003). The Dynamic Resource-Based View: Capability Lifecycles Strategic. Management Journal, 24 (Special Issue), 997-1010.

Helfat, C.E., Finkelstein, S., Mitchell, W., Peteraf, M.A., Singh, H., Teece, D.J. (2007). Dynamic Capabilities: Understanding Strategic Change in Organizations. Cambridge: Cambridge University Press.

Inkpen, A. (1998). Learning and Knowledge Acquisition through International Strategic Alliance. The Academy of Management Executive, 12 (4), 69-80.

Ireland, R.D., Hitt, M.A., Sirmon, D.G. (2003). A Model of Strategic Entrepreneurship: The Construct and Its Dimensions. Journal of Management, 29, 963-989.

Johanson, J., Vahlne, J.E. (1977). The Internationalization Process of the Firm: A Model of Knowledge Development and Increasing Foreign Market Commitment. Journal of International Business Studies, 8(1), 23-32.

Kanter, R. M. (1982). The Middle Manager as Innovator. Harvard Business Review, July-August, 95- 105.

Ketchen, D.J., Wowak, K.D., Craighead, C.W. (2014). Resource Gaps and Resource Orchestration Shortfalls in Supply Chain Management: The Case of Product Recall. Journal of Supply Chain Management, 50 (3), 6-15.

Ludwig, G., Pemberton, J. (2011). A Managerial Perspective of Dynamic Capabilities in Emerging Market: The Case of Russiam Stell Industry.Journal for East European Management Studies, 3, 215-236.

Maritan. C.A., Peteraf, M.A. (2011). Building a Bridge Between Resource Acquisition and Resource Accumulation. Journal of Management, 37(5), 1374-1389.

Mudambi, R. (1999). MNE Internal Capital Markets and Subsidiary Strategic Independence. International Business Review, 8, 197-211.

Nonaka, I. (1988). Creating Organizational Order Out of Chaos: Self-Renewal in Japanese Firms. California Management Review, 57-73.

O'Brien, D., Scot, P.S., Gibbons, P. (2012). Developing Strategy from the Middle: Subsidiary Strategy and The Role of the Subsidiary General Manager. Irish Journal of Management, 109-128.

Pedersen, T., Petersen, B. (2004). Learning about Foreign Markets: Are Entrant Firms Exposed to a "Shock Effect"? Journal of International Marketing, 12 (1), 103-123.

Paterson, S.L., Brock, D.M (2002). The Development of Subsidiary-Management Research: Review and Theoretical Analysis. International Business Review, 11, 139-163.

Peng, M.W. (2001). The Resource-Based View and International Business. Journal of Management, 27, 803829.

Pennings, J. M., Barkema, H. G., Douma, S. W. (1994). Organizational Learning and Diversification. Academy of ManagementJournal, 37, 608-640.

Rugman, A.M., Verbeke, A. (2001). Subsidiary-Specific Advantages in Multinational Enterprises. Strategic ManagementJournal, 22, 237-250. 
Schmid, S., Schurig, A. (2003). The Development of Critical Capabilities in Foreign Subsidiaries: Disentangling the Role of The Subsidiary's Business Network. International Business Review, 12,755-782.

Sirmon, D. G., Hitt, M. A. (2003). Managing Resources: Linking Unique Resources, Management and Wealth Creation in Family Firms. Entrepreneurship Theory and Practice, 27, 339-358.

Sirmon, D.G., Hitt, M.A., Ireland, R. D. (2007). Managing Firm Resources in Dynamic Environments to Create Value: Looking Inside The Black Box. Academy of Management Review, 32 (1), 273-292.

Sirmon, D.G., Hitt, M.A., Ireland, R.D., Gilbert, B.A. (2011). Resource Orchestration to Create Competitive Advantage: Breadth, Depth, Life Cycle Effects. Journal of Management, 37 (5), 1390-1412.

Subramaniam, M., Watson, S. (2006). How Interdependence Affects Subsidiary Performance. Journal of Business Research, 59, 916-924.

Teece, D.J. (2007). Explicating Dynamic Capabilities: The Nature and Microfoundation of (Sustainable) Enterprise Performance. Strategic ManagementJournal, 28, 1319-1350.

Teece, D.J., Pisano, G., Shuen, A. (1997). Dynamic Capability and Strategic Management. Strategic Management Journal, 18 (7), 509-533. 